\title{
Molecular Cloning and Characterization of Genes Expressed during Early Tomato (Lycopersicon esculentum Mill.) Fruit Development by mRNA Differential Display
}

\author{
Denise M. Tieman ${ }^{2}$ and Avtar K. Handa ${ }^{1}$ \\ Department of Horticulture, Purdue University, 1165 Horticulture Building, West Lafayette IN 47907-1165
}

Additional index words. expressed sequence tags

\begin{abstract}
The growth of tomato fruit is the result of cell division early in development followed by cell expansion until the onset of ripening. We have utilized the mRNA differential display technique to clone genes differentially expressed in 10and 20-day-old tomato fruit, when most fruit cells are undergoing a transition to growth by cell expansion. Of 1753 total bands observed using 30 independent primer sets, 31 differential display bands were obtained only in either 10-or 20-day old fruit RNAs. Seven differentially expressed bands from 10-day-old fruit RNAs and six from 20-day-old fruit RNAs were cloned and characterized by sequence analysis and mRNA expression patterns in developing fruit, leaf and root tissues. Two clones had sequence similarities to 3-deoxy-D-arabino-heptulosonate-7-phosphate (DAHP) synthase or threonine deaminase genes, while the remaining clones did not correspond to previously characterized genes. Steady state levels of mRNAs corresponding to seven clones were upregulated between 10 and 20 days of fruit development, while two clones were downregulated during growth and ripening. Most clones also hybridize to mRNA species present in leaf and root tissues. Collectively, these results suggest a transition in gene expression between 10- and 20-day-old fruit development.
\end{abstract}

Cell expansion, in addition to cell division, plays a very significant role in overall plant growth and development. It is generally believed that an interplay between cell wall loosening and cell wall biosynthesis is involved in plant cell expansion. The roles of several cell wall hydrolyses, including glucanases, xyloglucan endotransferases, cell wall structural proteins, and proteins that induce cell wall extension in isolated cell walls are being studied to understand cell expansion in plant cells (Cooper et al., 1994, Cosgrove, 1993, McQueen-Mason and Cosgrove, 1994, McQueen et al., 1992, Soni et al., 1995, Taiz, 1994). Expansion of plant cells in response to increased levels of auxin is believed to be due to increased wall extensibility and solute uptake (Carpita and Gibeaut, 1993, Rayle and Cleland, 1992). Thus understanding the roles of genes involved in auxin induced cell enlargement, including osmoregulation, will also provide fundamental information towards our understanding of cell expansion (Guilfoyle et al., 1993, Hobbie and Estelle, 1994, Li et al., 1994).

Developing fruits offer an excellent system to study the process of cell expansion. Growth of many fruit is characterized by a single sigmoidal growth curve with an initial stage of slow growth by cell division, followed by rapid growth mainly by cell expansion until the onset of ripening (Coombe, 1976, Rhodes, 1980). Tomato (Lycopersicon esculentum Mill.) fruit growth is mainly a result of cell division until about 7 to 12 days after pollination and by cell expansion thereafter, except in the outer layers of the pericarp and placenta, where some cell division occurs during the cell expansion phase (Gillaspy et al., 1993, Varga and Bruinsma, 1986). Although many fruit ripening related genes have been cloned, little

Received for publication 30 May 1995. Accepted for publication 31 Aug. 1995. Journal paper no. 14,632 of the Purdue Univ. Agricultural Research Station. We thank Joel Gaffe and K.G. Raghothama, W.R. Woodson, and Kurt Kausch for critical reading of the manuscript. The research was supported by a consortium for plant biotechnology research grant. The cost of publishing this paper was defrayed in part by the payment of page charges. Under postal regulations, this paper therefore must be hereby marked advertisement solely to indicate this fact.

'To whom reprint requests should be addressed,

${ }^{2}$ Current address: Horticultural Science Department, Univ. of Florida, Fifield Hall, Gainesville, FL 32611-0690. attention has been focused on the earlier stages of fruit development, including cell expansion (Fischer and Bennett, 1991, Gillaspy et al., 1993). Knowledge of changes in gene expression and molecular cloning of specific genes involved in this process may lead to a better understanding of the determinants of fruit size and yield.

We have used the mRNA differential display technique first reported by Liang and Pardee (1992) to understand the changes in gene expression during the transition between the cell division and cell expansion phases in developing tomato fruit. This is a PCR-based technique that facilitates the cloning of most mRNAs, including rare RNAs that maybe difficult to clone with techniques such as subtractive cloning and differential screening of cDNA libraries (Liang and Pardee, 1992). This technique enables one to both identify and clone genes that are differentially expressed in different cell types in mammalian systems (Aiello et al., 1994, Liang et al., 1992, Nishio et al., 1994, Sager et al., 1993, Utans et al., 1994, Zimmerman and Schultz, 1994). In the present paper, we report the cloning of sever-d genes that show differential expression in 10- and 20-day-old fruit by the mRNA differential display technique and characterize their expression patterns during fruit development and ripening and in leaves and roots of the tomato plant.

\section{Materials and Methods}

Plant material. 'Rutgers' tomato plants were grown under standard greenhouse conditions as described earlier (Biggs and Handa, 1989). Flowers were hand pollinated and pericarp tissue from 10- and 20-day-old fruit was frozen in liquid nitrogen and stored at $-80 \mathrm{C}$ until use. Leaf and root tissues of mixed maturity from greenhouse grown plants were harvested and frozen in liquid nitrogen until use.

mRNA differential display. mRNA differential display was performed as described by Liang and Pardee (1992) with some modifications. Total RNAs from fruit harvested at 10 or 20 days after flowering (DAF) were extracted as described earlier (Biggs and Handa, 1989). Twenty five micrograms of total RNAs were treated 
with RNase free DNaseI (Boehringer Mannheim, Indianapolis, Ind.) at $37 \mathrm{C}$ for $30 \mathrm{~min}$ in the presence of human placental ribonuclease inhibitor (United States Biochemical, Cleveland, Ohio). After phenol : chloroform extraction and ethanol precipitation, the DNasetreated RNA was diluted to $0.1 \mu \mathrm{g} \cdot \mu^{-1}$. Reverse transcriptase reactions were performed on $0.2 \mathrm{mg}$ DNA free RNA in $1 \times$ reverse transcriptase buffer (United States Biochemical), $20 \mu \mathrm{M}$ each dGTP, dATP, dCTP, dTTP, and $1 \mathrm{~mm}$ primer $\left(5^{\prime} \mathrm{T}_{11} \mathrm{AC}, 5^{\prime} \mathrm{T}_{11} \mathrm{CG}\right.$, or $\left.5{ }^{\prime} \mathrm{T}_{11} \mathrm{AG}\right)$. The reverse transcriptase reaction mixture was incubated for $5 \mathrm{~min}$ at $65 \mathrm{C}$ followed by $10 \mathrm{~min}$ at $37 \mathrm{C}$ before adding 250 units of MMLV-reverse transcriptase (United States Biochemical). The mixture was incubated at $37 \mathrm{C}$ for an additional $50 \mathrm{~min}$ before termination by heating at $95 \mathrm{C}$ for $5 \mathrm{~min}$. PCR was performed on onetenth volume of the reverse transcriptase reaction mixture in $1 \times \mathrm{PCR}$ buffer $(50 \mathrm{~mm} \mathrm{KCl}, 10 \mathrm{~mm}$ Tris-HCl, pH 8.0,0.1\%. Triton X-100 (v/ v), $2 \mathrm{mM} \mathrm{MgCl}_{2}$ ) containing $2 \mu \mathrm{M}$ each dATP, dCTP, dGTP, and dTTP, $1 \mathrm{mM} \mathrm{T}_{11} \mathrm{AC}, \mathrm{T}_{11} \mathrm{CG}$, or $\mathrm{T}_{11} \mathrm{AG}$ primer (the same as in the reverse transcriptase reaction), $0.2 \mathrm{~mm}$ of a random 10 -mer primer (5'CGC,AGT,ACTC, 5'GTC,CTA,CTCG, 5'CTA,CAC,AGGC, 5'GTC,CTT,AGCG， 5'GTC,CTC,AACG， 5'CTA,CTA,CCGC, 5'GAG,TCA,CTCG, 5'GTC,CTC,AGTG, 5'CGT,CGT,TACC, or 5'GCA,GAC,TGAG), $10 \mu \mathrm{Ci}\left[\alpha-\mathrm{S}^{35}\right] \mathrm{dATP}\left(>1000 \mathrm{Ci}^{\prime} \mathrm{mol}^{-1}\right)$, and 5 units Taq DNA polymerase (Promega, Madison, Wis.). PCR reactions were performed as follows: $94 \mathrm{C}$ for 30 see, $40 \mathrm{C}$ for 2 rein, $72 \mathrm{C}$ for $30 \mathrm{sec}$, for 40 cycles, followed by $72 \mathrm{C}$ for $5 \mathrm{~min}$. The PCR products containing tracking dye were separated on a $5 \%(\mathrm{w} / \mathrm{v})$ polyacrylamide sequencing gel containing $7 \mathrm{M}$ urea with differential display reactions from 10- and 20-day-old fruit RNAs with the same PCR primers run in adjacent lanes. The gel was dried without fixing and autoradiographed on Kodak XAR-5 film.

Retrieval and cloning of differential display products Differences in banding patterns between 10 day and 20 day differential display reactions were identified and the bands corresponding to these differences excised from the dried gels. Each gel slice was incubated in $100 \mu \mathrm{TE}(10 \mathrm{~mm}$ Tris- $\mathrm{HCl}, 1 \mathrm{~mm}$ EDTA, pH 8.0) at $37 \mathrm{C}$ for $1 \mathrm{~h}$ to release PCR products. The eluted PCR products were subjected to PCR in a reaction mixture $(40 \mu \mathrm{l})$ containing $5 \mu \mathrm{l}$ of the gel slice eluate, $1 \times \mathrm{PCR}$ buffer, $2 \mathrm{~mm} \mathrm{MgCl}_{2}, 20 \mathrm{~mm}$ dNTPs, 1 $\mu \mathrm{M}$ respective $\mathrm{T}, \mathrm{MN}$ primer, $0.2 \mu \mathrm{M}$ respective random $10 \mathrm{mer}$ primer, and 10 units Taq DNA polymerase for 40 cycles at $94 \mathrm{C}$ for $30 \mathrm{see}, 40 \mathrm{C}$ for $2 \mathrm{~min}$ and $72 \mathrm{C}$ for $30 \mathrm{sec}$. A portion of the PCR product was electrophoresed on a $1.5 \%(\mathrm{w} / \mathrm{v})$ agarose gel to confirm amplification of the DNA fragment. The PCR product was then cloned into cloning vector PCRII (Invitrogen, San Diego, Calif.) or T-tailed pBluescript SK (Marchuk et al., 1991 ).

RNA Gel Blot Analysis Poly A ${ }^{+}$RNAs from fruit harvested at 10 or 20 DAF were extracted as described earlier (Biggs and Handa, 1989). Northern blot analysis of poly $\mathrm{A}^{+} \mathrm{RNA}$ was performed using ${ }^{32} \mathrm{P}$-labelled inserts from the differential display clones as probes at a hybridization temperature of 55C (Harriman et al., 1991). Blots were washed in $1 \times$ SSPE $(1 \times$ SSPE contains $180 \mathrm{~mm} \mathrm{NaCl}, 10 \mathrm{~mm} \mathrm{Na}$ phosphate, $1 \mathrm{~mm}$ EDTA, $\mathrm{pH} 7.4$ ) for $15 \mathrm{~min}$ at $25 \mathrm{C}$ followed by two washes in $0.5 \times \mathrm{SSCPE}, 0.1 \%$ SDS $(\mathrm{w} / \mathrm{v})$ for $15 \mathrm{~min}$ each at $55 \mathrm{C}$ Blots were stripped according to the manufacturer's (Schleicher and Schuell, Keene, N.H.) instructions and reprobed. Polygalacturonase (PG) and pectin methylesterase (PME) RNA gel blot analyses were performed using ${ }^{32} \mathrm{P}$-labelled inserts from full length $\mathrm{PG}$ and PME cDNA clones with a hybridization temperature of 65C (Biggs and Handa, 1989, Harriman et al., 1991).

Sequence Analysis. DNA sequencing was performed by dideoxy termination method (Sanger et al., 1977 using a Sequenase II kit (United States Biochemical). Sequences were compared to the National Center of Biotechnology Information nonredundant se- quence database using the BLASTX and BLASTN programs (Altschul et al., 1990, Gish and States, 1993). Significant sequence similarity at the nucleotide level was defined as at least $50 \%$ identity over the entire length of the clone.

Chemicals Acrylamide, bis-acrylamide, agarose, urea, SDS, TRIS were purchased from United States Biochemical. dNTPs, Ficoll, BSA, PVP, NaCl, sodium citrate, EDTA were from Sigma Chemical Company, St. Louis. All other chemicals were of the reagent grade.

\section{Results}

Comparison of mRNA populations in 10- and 20-day-old tomato fruit using $m R N A$ differential display. The mRNA differential display technique (Liang and Pardee, 1992) was used to examine differences in gene expression between 10- and 20-day old tomato fruit at the transcriptional level. Since most cell division in tomato pericarp ceases by 10 DAF (Gillaspy et al., 1993), RNAs from 10- and 20-day-old fruit were selected to isolate genes primarily expressed during cell expansion. Ten random primers and three anchor primers were used for a total of 30 differential display reactions with an average of about 60 bands amplified with each primer set (Table 1). Table 1 shows the approximate total number of bands, as well as the number of reproducible differences between 10 and 20-day-old fruit RNAs found with each primer set. Among the 1753 amplified bands in all differential display reactions, 18 were obtained only from 10 day fruit RNA, while 13 were present only from 20 day fruit RNA. This analysis is based on duplicate differential display reactions with each primer set to ensure that the differences were reproducible. We did, however, see bands which were not reproducible in two independent differential display reactions using the same set of primers.

Molecular cloning and characterization of deferentially displayed DNA fragments. Thirteen bands (seven from 10-day-old and six from 20-day-old fruit RNA) differentially displayed in either 10- or 20-day-old fruit RNA were cloned and sequenced. Insert sizes and identities of cloned DNA fragments to known sequences in the databases are summarized in Table 2. Clones designated with numbers beginning in 10 or 20 were from differential display reactions from 10- or 20-day-old fruit RNAs, respectively. Sequence analysis revealed predominantly A/T-rich inserts

Table 1. Number of total and differentially displayed bands visible on differential display gels using RNAs from 10- and 20-day-old tomatoes. Three anchor primers and 10 random primers, as indicated, were used in 30 independent differential display reactions. Shown are total bands and bands reproducibly obtained from either 10- day or 20-day old fruit RNAs.

\begin{tabular}{|c|c|c|c|c|c|c|c|c|c|}
\hline \multirow[b]{3}{*}{ Random primer } & \multicolumn{9}{|c|}{ Anchor primer } \\
\hline & \multicolumn{3}{|c|}{$5^{\prime}-(\mathrm{T})_{11} \mathrm{AC}$} & \multicolumn{3}{|c|}{$5^{\prime}-(\mathrm{T})_{11} \mathrm{CG}$} & \multicolumn{3}{|c|}{$5^{\prime}(\mathrm{T})_{11} \mathrm{AG}$} \\
\hline & Total & $10 \mathrm{~d}$ & $20 \mathrm{~d}$ & Total & $10 \mathrm{~d}$ & $20 \mathrm{~d}$ & Total & $10 \mathrm{~d}$ & $20 \mathrm{~d}$ \\
\hline 5'-CGCAGTACTC & 59 & 1 & 3 & 18 & 0 & 0 & 87 & 0 & $\overline{0}$ \\
\hline 5'-GTCCTACTCG & 54 & 1 & 0 & 18 & 0 & 0 & 72 & 0 & 2 \\
\hline 5'-CTACACAGGC & 60 & 0 & 0 & 56 & 0 & 0 & 73 & 0 & 2 \\
\hline 5'-GTCCTTAGCG & 76 & 0 & 0 & 18 & 0 & 0 & 75 & 0 & 0 \\
\hline 5'-GTCCTCAACG & 71 & 3 & 0 & 51 & 0 & 4 & 110 & 0 & 1 \\
\hline 5'-CTACTACCGC & 43 & 0 & 0 & 45 & 2 & 0 & 49 & 0 & 0 \\
\hline 5'-GAGTCACTCG & 45 & 0 & 0 & 66 & 0 & 0 & 76 & 1 & 1 \\
\hline 5'-GTCCTCAGTG & 25 & 0 & 0 & 53 & 0 & 0 & 69 & 0 & 0 \\
\hline 5'-CGTCGTTACC & 43 & 4 & 0 & 91 & 1 & 0 & 41 & 1 & 0 \\
\hline 5'-GCAGACTGAG & 56 & 1 & 0 & 77 & 0 & 0 & 76 & 3 & 0 \\
\hline Total & 532 & 10 & 3 & 493 & 3 & 4 & 728 & 5 & 6 \\
\hline
\end{tabular}


Table 2. Insert sizes, sequence homology to reported genes, A/T content, and approximate size of hybridizing mRNA clones obtained by mRNA differential display.

\begin{tabular}{|c|c|c|c|c|c|c|}
\hline Clone & $\begin{array}{c}\text { Probe } \\
\text { size }(b p)^{z}\end{array}$ & $\begin{array}{c}\text { Approximate } \\
\text { mRNA size }(\mathrm{kb})\end{array}$ & $\% \mathrm{~A} / \mathrm{T}^{y}$ & $\begin{array}{c}\text { Sequence } \\
\text { homology }^{x}\end{array}$ & Display primers & $\begin{array}{c}\text { Accession } \\
\text { no. }\end{array}$ \\
\hline$\overline{10-6}$ & 109 & $\mathrm{~N} \mathrm{D}^{\mathrm{W}}$ & 65 & Unknown & GTCCTCAACG, $(\mathrm{T})_{11} \mathrm{AC}$ & U21073 \\
\hline $10-8$ & 338 & 2.0 & 71 & Threonine deaminase & CGTCGTTACC, $(\mathrm{T})_{11} \mathrm{AC}$ & U21082 \\
\hline $10-9$ & 286 & 1.5 & 66 & Unknown & CGTCGTTACC, $(\mathrm{T})_{\Perp} \mathrm{AC}$ & U21084 \\
\hline $10-10$ & 212 & 1.1 & 65 & Unknown & CGTCGTTACC, $(\mathrm{T})_{11}$ AC & U21077 \\
\hline $10-23$ & 213 & ND & 67 & Unknown & CGTCGTTACC, $(\mathrm{T})_{11}$ AG & U21075 \\
\hline $10-30$ & 174 & 1.5 & 74 & Unknown & GTCCTCAACG, $(\mathrm{T})_{11} \mathrm{AC}$ & U21085 \\
\hline $10-39$ & 223 & $0.5,0.9$ & 74 & Unknown & CTACTACCGC, $(\mathrm{T})_{11} \mathrm{CG}$ & U21083 \\
\hline $20-2$ & 240 & 0.5 & 62 & Unknown & CGCAGTACTC, $(\mathrm{T})_{11} \mathrm{AC}$ & U21078 \\
\hline $20-3$ & 208 & 1.5 & 59 & Unknown & CGCAGTACTC, $(\mathrm{T})_{11} \mathrm{AC}$ & U21079 \\
\hline $20-12$ & 359 & 0.9 & 63 & Unknown & GTCCTCAACG, $(\mathrm{T})_{11} \mathrm{CG}$ & U21076 \\
\hline $20-13$ & 342 & $0.8,2.0$ & 71 & Unknown & GTCCTACTCG, $(\mathrm{T})_{11} \mathrm{CG}$ & U21074 \\
\hline $20-14$ & 338 & 2.4 & 62 & DAHP synthase & GTCCTACTCG, $(\mathrm{T})_{11} \mathrm{CG}$ & U21081 \\
\hline $20-27$ & 233 & 1.5 & 71 & Unknown & CTACACAGGC, (T) $11 \mathrm{AG}$ & U21080 \\
\hline
\end{tabular}

${ }^{\overline{ }}$ Probe size is total base pairs as determined by sequence analysis and includes the primers (23 bp) used for differential display PCR. 'percent $\mathrm{A} / \mathrm{T}$ was calculated over the entire insert length including the 5' random primer.

${ }^{\mathrm{x}}$ Sequences have been deposited in the GenBank.

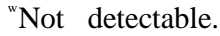

\section{MG Ri Lf Rt}

$10-8$

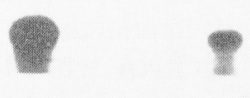

10-9

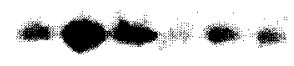

10-10

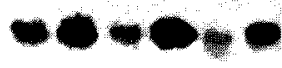

10-30

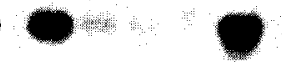

10-39

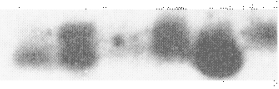

PG

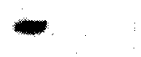

PME

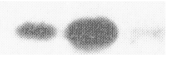

1020 MG Ri Lf Rt

20-2

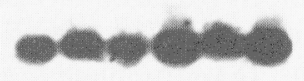

20-3

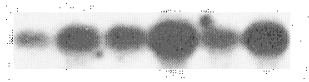

20-12

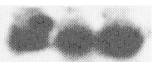

20-13

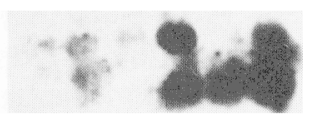

20-14

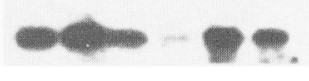

20-27

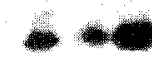

Fig. 1. Changes in the steady state levels of mRNAs corresponding to cDNA clones obtained from the differential display of 10- and 20 day-old fruit RNAs during tomato fruit development and ripening, and leaf and root tissues. Poly A RNA $(0.75$ $\mu \mathrm{g}$ ) was electrophoresed on agarose gels, blotted to nitrocellulose, and probed with the differential display clone inserts. Due to the relatively short probes rich in A/T sequences, lower signal to noise ratios were observed in all RNA blots. Clones starting with 10 and 20 were obtained from 10- and 20-day-old fruit RNAs, respectively. Abbreviations are as follows: 10 and 20, fruit obtained 10 and 20 days after flowering; MG, mature green fruit; Ri, red ripe fruit Lf, leaf; Rt, root; PG, polygalacturonase; PME, pectin methylesterase; 10-8, 10-9, 10-10, 10-30 and 1039 , cDNA clones isolated from 10-day-old fruit RNA; 20-2,20-3,20-12,20-13, 2014 and 20-27, cDNA clones isolated from 20-day-old fruit RNA.

109 to 359 bp in length with identifiable primer sequences (Table 2). Based on comparison to the National Center on Biotechnology Information nonredundant database, only two of these clones (108 and 20-14) had significant similarity to previously cloned genes (Table 2). Clone 10-8 showed 100\% nucleotide sequence identity

excluding the primer sequences to the $3^{\prime}$ end of a tomato threonine deaminase cDNA including the $3^{\prime}$ coding and untranslated regions, but was $28 \mathrm{bp}$ shorter at the 3 ' end than the published cDNA (Samach et al., 1991). Clone 20-14 had significant similarity to the 3 ' untranslated regions of both tomato and potato DAHP synthase cDNAs. Clone $20-14$ was $100 \%$ identical to a tomato DAHP synthase excluding the primer sequences, but contained $168 \mathrm{bp}$ beyond the $3^{\prime}$ end of the published sequence of this gene. This $3^{\prime}$ extension contains significant similarity to a potato DAHP synthase. Overall clone $20-14$ is about $89 \%$ identical to potato DAHP synthase when gaps of 18 and $21 \mathrm{bp}$ are inserted for maximal sequence alignment. No other clone showed significant similarity to sequences in the databases at either nucleotide or translated amino acid levels (data not shown).

Expression patterns of cloned differential display genes during fruit development and ripening and in vegetative tissues. Fig. 1 shows the changes in steady state levels of mRNAs which hybridized to the cloned DNA inserts during tomato fruit development and ripening and in leaf and root tissues. All clones, except 10-6 and 10-23, hybridized to RNA species ranging from 0.5 to $2.4 \mathrm{~kb}$ (Table 2). Absence of hybridization signal with clone 10-6 could be due to the small insert (109 bp including primers) with high $(65 \%) \mathrm{A} / \mathrm{T}$ content (Table 2). Clone 10-23 had a relatively larger insert (213 bp), therefore the absence of hybridizable signal could be due to a very low abundance transcript. Among the clones isolated from 10-day-old fruit RNAs, only clones 10-8 and 10-30 hybridized to RNAs which exhibited differential expression between 10-day-old fruit and later stages of fruit development, while three clones were upregulated between 10- and 20-day-old fruit development. Of the clones from 20-day-old fruit RNA, three (Clone 20-3, 20-12 and 20-13) hybridized to RNAs, which were upregulated in 20-day-old fruit as compared to 10-day-old fruit, while three showed virtually no change between the two stages (Fig. 1).

The expression patterns of the cloned genes varied throughout development and ripening and in leaf and root tissues (Fig. 1). Clone 10-8, a threonine deaminase homologue, hybridized to an RNA detectable only in 10 day fruit and leaf tissues. Clone 10-30 hybridized to an RNA, which showed much higher mRNA levels in 10 day fruit and leaf tissues compared to 20 day, mature green (MG) and ripe (Ri) fruit and root tissues; Clones 10-9 and 10-10 hybridized to RNAs which were expressed in all tissues examined 
with the highest level of mRNA detected in 20-day-old fruit for clone 10-9, and in Ri fruit and root tissues for clone 10-10. Between the two RNA species hybridizing to clone 10-39, one was present at the highest levels in 20-day-old fruit and leaf tissues, while the other accumulated preferentially in 20-day-old and Ri fruit.

Clones 20-2 and 20-3 hybridized to RNAs which showed similar accumulation patterns throughout fruit development and ripening and in leaf and root tissues, although clone 20-3 hybridized to an RNA species which was unregulated between 10- and 20-day-old fruit. Clone 20-12 hybridized to an RNA species which was slightly upregulated between 10- and 20-day-old fruit with much higher accumulation in Ri fruit and leaf and root tissues. Clone 20-13 hybridized to two RNA species in fruit and root and one RNA species from leaf. Both of these species were upregulated between 10- and 20-day-old fruit and accumulated to much higher levels in ripe fruit. Clone 20-14 (a DAHP synthase homologue) exhibited higher levels of hybridizable RNA species in 10-day old, 20-day-old, and MC fruit, root and leaf tissue, which were down regulated in ripe fruit. Higher levels of mRNA for clone 2027 were obtained in ripe fruit, leaf and root RNAs compared to 10day-old, 20-day-old, or MC fruit RNAs. The expected expression patterns were observed for polygalacturonase (PC) and pectin methylesterase (PME) mRNAs used as controls (Biggs and Handa, 1989, Harriman et al., 1991). PG RNA was detectable only in ripe fruit, while PME RNA was first detectable in 20-day-old fruit, increased at the MG stage and decreased in ripe fruit. Neither PME nor PG mRNA was detectable in leaf or root tissue.

\section{Discussion}

We have used the differential display technique to identify and clone genes whose expression patterns change during early fruit development. This is the period of fruit ontogeny when there is a transition in growth by predominantly cell division to predominantly cell expansion. Based on 30 differential display reactions, it seems that about $1 \%-2 \%$ of the mRNA population undergoes changes between 10- and 20-day-old fruit pericarps. However, among the clones obtained by differential display only a portion showed the expected differential expression patterns of mRNA accumulation. Due to the mixed population of cells present in developing pericarp, further analysis using in situ cellular localization is needed before assigning expression of the cloned genes to regions undergoing cell division or cell expansion. Collectively, these results suggest a transition in gene expression between 10and 20-day-old fruit. Further studies of these genes should improve our knowledge of the basis of transitions between cell division and cell expansion phases in developing tomato fruit.

The differential display clones have varying expression patterns; however none of the clones exhibits fruit specific expression. All of the clones examined had at least some expression in leaf tissues, whereas only clones 10-8 and 10-30 were not detected in root tissues. The presence of the mRNAs corresponding to these clones in fruit, leaf, and root tissues may indicate that the function of the encoded proteins is necessary for processes essential to developing tissues. Also, it has been suggested that the carpels are modified leaves, which fuse to form the ovary (Gillaspy et al., 1993). Two clones were constitutively expressed throughout ripening and in leaf and root tissues. Four genes were unregulated between 10 and 20 days, whereas two genes were down regulated during this period. Five clones hybridized to RNAs which increased during ripening, and three to RNAs which decreased during ripening. It is interesting that while two clones hybridize to RNAs which were significantly downregulated between 10 and 20 days, none hybridized to mRNAs which were present in 20-day-old fruit but absent in 10-day-old fruit. This result may bean indication of the continuous expansion of cells throughout the developmental process. In the pericarp tissues used in this study, it is likely that some cells are undergoing expansion throughout development (Gillaspy et al., 1993). Alternatively, it is possible that isolation and characterization of more clones from 20day-old fruit would result in cDNAs that are expressed in 20-day-old fruit but not 10-day-old fruit. Clones 10-39 and 20-13 hybridized to two mRNA species with varying expression patterns, which may indicate a family of genes encoding mRNAs of different sizes or two independent genes with significant homology at the $3^{\prime}$ ends of the transcripts. Hybridization of a cDNA probe to mRNA species differing in molecular size has been observed in various organisms, including plants (Corbin et al., 1987, Henstrand and Handa, 1989).

Clone $10-8$ has $100 \%$ identity to the $3^{\prime}$ end of threonine deaminase, the first committed step in the pathway for isoleucine biosynthesis. This enzyme is particularly upregulated in floral organs, and is the most abundant protein in tomato flowers (Samach et al., 1991). Threonine deaminase mRNA levels have been reported to be 2-5 times higher in young fruit than in leaves (Samach et al., 1991), a result similar to that observed in the present study (Fig. I). We have not detected threonine deaminase RNA in 20-day-old, MG, or Ri fruit, suggesting its downregulation during fruit development. Clone 20-14 has significant similarity to tomato LeDHS1 and potato $s h k B$ DAHP synthase genes (Goerlach et al, 1993, Zhao and Herrmann, 1992). LeDHS1 mRNA accumulation has been reported in leaf and root as seen in the present study (Goerlach et al, 1993). Interestingly, clone 20-14 contains 168 nucleotides beyond the 3' end of the published tomato LeDHS1 (Goerlach et al., 1993), and the extended sequence shares significant identity to potato $\operatorname{shkB}$ (Zhao and Herrmann, 1992).

Plants genes, unlike mammalian genes, do not have a specific consensus sequence for polyadenylation of transcripts, and often plant mRNAs from a single gene are polyadenylated at several different sites (Hunt, 1994). It is likely that we have obtained clone 20-14 from an mRNA with a polyadenylation site different from the six sites already reported for LeDHS1 (Goerlach et al, 1993). The basis of selection of a particular polyadenylation site during transcription of a plant gene, if any, is not known (Hunt, 1994). However, this redundancy in polyadenylation sites would result in differences in the banding patterns in the differential display gel by amplification of mRNAs with different polyadenylation sites. Given the tendency for plant mRNAs to have several polyadenylation sites, it would be necessary to screen more differential display clones from plant tissues to identify genes which are differentially expressed between two developmental stages. It may also be possible to start with more RNA in the differential display reactions to achieve better representation of all possible mRNA termination sites. Liang, et al. (1993) have noted that increasing RNA concentrations can result in more bands on differential display gels. Interestingly, we have identified several differential display clones from the same primer set, but homologies with different polyadenylation sites were not obtained (Tables 1 and 2). Perhaps the use of anchored poly dT primers with two nondegenerate 3' bases increased the specificity y of the subset of RNAs amplified, and thus reduced the possibility of identifying homologies sequences with differing 3' termination sites.

We and others have noted that some mRNA differential display results do not correlate with RNA expression data (Fig. 1, Aiello et al., 1994, Utans et al., 1994). Only one clone (10-8) of the 11 clones characterized using RNA blotting showed the expected differential mRNA accumulation pattern. Furthermore, clones 109 and 10-10 are upregulated during fruit development (Fig. 1), yet 
we isolated it from a band differentially displayed in 10 day fruit RNA. The presence of more than one amplified RNA species in a differential display band resulting in a mixed population of cloned products would result in this discrepancy. This problem may be circumvented by characterizing expression of several independent clones from the same differential display band using RNA blot analysis (Liang et al., 1993). Since we have only characterized one clone obtained from each band, other clones from the same band may have expression patterns better correlated with the differential display results. Utans et al. ( 1994) noted that only 4 of 12 differential display clones were unregulated in rejected transplanted cardiac tissue when analyzed by RNA blotting. Together, the results demonstrate that mRNA differential display is a useful technique to isolate differentially regulated genes, but like other methods it has limitations.

\section{Literature Cited}

Aiello, L.P., G.S. Robinson, Y.-W. Lin, Y. Nishio, and G.L. King. 1994. Identification of multiple genes in bovine retinal pericytes altered by exposure to elevated levels of glucose by using mRNA differential display. Proc. Natl. Acad. Sci. USA 91:6231-6235.

Altschul, S.F., W. Gish, W. Miller, E.W. Myers, and D.J. Lipman. 1990. Basic local alignment search tool. J. Mol. Biol. 215:403-410.

Biggs, M.S. and A.K. Handa. 1989. Temporal regulation of polygalacturonase gene expression in fruits from normal mutant and heterozygous tomato genotypes, Plant Physiol. 89:117- 125.

Carpita, N.C. and D.M. Gibeaut. 1993. Structural models of primary cell walls in flowering plants: Consistency of molecular structure with the physical properties of the walls during growth. Plant J. 3:1-30.

Coombe, B.G. 1976. The development of fleshy fruits. Annu. Rev. Plant Physiol. 27:507-528.

Cooper, J.B., J.E. Heuser, and J.E. Varner. 1994. 3,4-Dehydroproline inhibits cell wall assembly and cell division in tobacco protoplasts. Plant Physiol, 104:747-752.

Corbin, D.R., N. Sauer, and C.J. Lamb. 1987. Differential regulation of hydroxyproline-rich glycoprotein gene family in wounded and infected plants. Mol. Cell Biol. 7:4337-4344.

Cosgrove, D.J. 1993, How do plant cell walls extend? Plant Physiol. 102:1-6.

Fischer, R.L. and A.B. Bennett. 1991. Role of cell wall hydrolases in fruit ripening. Annu. Rev. Plant Physiol. Plant Mol. Biol. 42:675-703.

Gillaspy, G., H. Ben-David, and W. Gruissem. 1993. Fruits: A developmental perspective. Plant Cell 5:1439-1451.

Gish, W., and D.J. States. 1993. Identification ofprotein coding regions by database similarity search. Nat. Genet. 3:266-272.

Goerlach, J., A. Beck, J.M. Henstrand, A.K. Handa, K.M. Herrmann, J. Schmid, and N, Amrhein. 1993. Differential expression of tomato (Lycopersicon esculentum L.) genes encoding shikimate pathway isoenzymes. I.3-Deoxy-D-arabino-heptulosonate-7-phosphate synthase. Plant Mol. Biol. 23:697-706,

Guilfoyle, T.J., G. Hagen, Y. Li, T. Ulmasov, Z. Liu, T. Strabala, and M. Gee. 1993. Auxin-regulated transcription. Austral. J. Plant Physiol. 20:489-502.

Harriman, R.W., D.M. Tieman, and A.K. Handa. 1991. Molecular cloning of tomato pectin methylesterase gene and its expression in Rutgers, ripening inhibitor, nonripening, and never ripe tomato fruits. Plant Physiol. 97:80-87.

Henstrand, J.M. and A.K. Handa. 1989. Effect of ethylene action inhibitors upon wound-induced gene expression in tomato pericarp. Plant
Physiol. 91:157-162.

Hobbie, L. and M. Estelle. 1994. Genetic approaches to auxin action. Plant Cell Environ, 17:525-540.

Hunt, A.G. 1994. Messenger RNA 3' end formation in plants. Annu. Rev. Plant Physiol. Plant Mol. Biol. 45:47-60.

Li, Y., Z.-B. Liu, X. Shi, G. Hagen, and T.J. Guilfoyle. 1994. An auxininducible element in soybean SAUR promoters. Plant Physiol. 106:3743.

Liang, P., L. Averboukh K. Keyomarsi, R. Sager, and A.B. Pardee. 1992. Differential display and cloning of messenger RNAs from human breast cancer versus mammary epithelial cells. Cancer Res. 52:6966-6968.

Liang, P., L. Averboukh, and A.B. Pardee. 1993. Distribution and cloning of eukaryotic mRNAs by means of differential display: Refinements and optimization Nucleic Acids. Res. 21:3269-3275.

Liang, P. and A.B. Pardee. 1992. Differential display of eukaryotic messenger RNA by means of the polymerase chain reaction. Science 257:967-971.

Marchuk; D., M. Drumm, A. Saulino, and F.S. Collins. 1991. Construction of T-vectors, a rapid and general system for direct cloning of unmodified PCR products. Nucleic Acids. Res. 19:1154,

McQueen-Mason, S., and D.J. Cosgrove. 1994. Disruption of hydrogen bonding between plant cell wall polymers by proteins that induce wall extension. Proc. Natl. Acad. Sci. USA 91:6574-6578.

McQueen, S., D.M. Durachko, and D.J. Cosgrove. 1992. Two endogenous proteins that induce cell wall extension in plants. Plant Cell 4:1425-1433.

Nishio, Y., L.P. Aiello, and G.L. King. 1994. Glucose induced genes in bovine aortic smooth muscle cells identified by mRNA differential display. FASEB J. 8:103-106.

Rayle, D.L. and R.E. Cleland, 1992. The acid growth theory of auxininduced cell elongation is alive and well. Plant Physiol. 99: 1271-1274.

Rhodes, M.J.C. 1980, The maturation and ripening of fruits, p. 157-205. In: KV Thimann (cd.). Senescence in plants, CRC Press, Boca Raton, Fla.

Sager, R., A. Anisowicz, M. Neveu, P. Liang, and G. Sotiropoulou, 1993. Identification by differential display of alpha 6 integrin as a candidate tumor suppressor gene. FASEB J. 7:964-970.

Samach, A., D, Hareven, T. Gutfinger, S. Ken-Dror, and E. Lifschitz. 1991. Biosynthetic threonine deaminase of tomato: Isolation, structure, and upregulation in floral organs. Proc. Natl. Acad. Sci. USA 88:26782682 .

Sanger, F., S. Nicklen, and A.R. Cordson. 1977. DNA sequencing with chain terminating inhibitors. Proc. Natl. Acad. Sci. USA 74:5463-5467.

Soni, R., J.P. Carmichael, Z.H. Shah, and J.A.H. Murray. 1995. A family of cyclin D homologs from plants differentially controlled by growth regulators and containing the conserved retinoblastoma protein interaction motif. Plant Cell 7:85-103.

Taiz, L. 1994. Expansins: Proteins that promote cell wall loosening in plants. Proc. Natl. Acad, Sci. USA 91:7387-7389.

Utans, U., P. Liang, L.R. Wyner, M.J. Karnovsky, and M.E. Russell. 1994. Chronic cardiac rejection: Identification of five unregulated genes in transplanted hearts by differential mRNA display. Proc. Natl. Acad. Sci. USA 91:6462-6467.

Varga, A. and J. Bruinsma. 1986. Tomato, p. 461-480. In: SP Molselise (cd.). CRC Handbook of Fruit Set and Development. CRC Press, Boca Raton, Fla.

Zhao, J. and Herrmann, K.M. 1992. Cloning and sequencing of a second cDNA encoding 2-deoxy-D-arabino-heptulosonate7-phosphate synthase for Solanum tuberosum L. Plant Physiol, 100: 1075-1 076.

Zimmerman, J. W. and R.M. Schultz. 1994. Analysis of gene expression in the preimplantation mouse embryo: Use of mRNA differential display. Proc. Natl. Acad. Sci. USA 91:5456-5460. 